\title{
INDO-ISRAEL STRATEGIC COOPERATION: CHALLENGES AND IMPLICATIONS ON PAKISTAN
}

\author{
Qudsia Akram \\ Assistant Professor in the Department of International Relations, \\ Kinnaird College for Women Lahore, Pakistan, \\ qudsia.akram@kinnaird.edu.pk \\ Summaya Shahid \\ Post Graduate Student of the Department of International Relations, \\ Kinnaird College for Women Lahore, Pakistan \\ Laila Ahmed \\ Undergraduate Student of the Department of International Relations, \\ Kinnaird College for Women Lahore, Pakistan.
}

\begin{abstract}
This research work attempts to evaluate the Indo-Israel strategic cooperation in South Asia and the resultant security challenges and threats for Pakistan due to this partnership. Security dilemma has been used to explain the hostile arms race between India and Pakistan and why India is strengthening its strategic ties with Israel. In addition, in-depth strategic cooperation and the nature of Indo-Israel relations give the understanding about the defense cooperation existing between Tel Aviv and New Delhi. Even though there have been several obstacles to furthering their military ties, these factors have not been drastic enough to impact the defense and strategic relations between the two nations. The methodology of this research is based on the qualitative research method. This method is based on descriptive, historical, and explanatory approaches towards the concepts, issues, concerns, and strategies.
\end{abstract}

Keywords: Israel- India, Strategic partnership, Pakistan, South Asia, Cooperation

\section{INTRODUCTION}

India is a state situated in the south Asian region. The state came into existence after World War II as a result of the decolonization process. The country got independence on August 15, 1947. At the same time, Pakistan is a Muslim state, which gained independence from the British raj in World War II on August 14, 1947. And it happened to be the only Islamic country with nuclear capability. Israel refers to the Jewish state, which through Balfour Declaration by Britain, was created in Palestine on May 14, 1948. The land was based on the ideological philosophy of Judaism. This country was created as the result of the bloodshed of millions of Muslims. Many Muslim states do not recognize Israel due to unlawful occupation of the country on the land of Palestinian Muslims. Pakistan and India are both significant states of the Asian continent, and the relationship was built on the animosity between the two states just after independence in 1947. Pakistan came into existence based on Islamic ideology, while India, although a secular state, always threw its weight against the Muslims. Kashmir is the primary the cause of conflict between the two nuclear nations.On the other hand, Israel, which happened to be a Jewish state, came into existence based on Jewish ideology. Israel's presence in Palestine land caused a conflicting situation in the middle east. This created strong resentment between the two communities. India and Israel both share a common enemy Pakistan, because of the Muslim tag on the nameplate of the country's identity. Both states used their strategic sources to maintain military might to counter common enemy Pakistan.

Historically, the strategic ties between New Delhi and Jerusalem were not strengthened throughout history and had a fair share of upheavals. Even though both states got their independence from the United Kingdom in a row, they found themselves headed in different directions for nearly 40 years. India stood as a leader in the Non-Aligned Movement and maintained close relations with the Soviet Union and the Arab world. In contrast, Israel linked her future to close bonds with Western Europe and the United States. In the 1950s, India extended de jure recognition for Israel and allowed 
her to maintain a consulate in Mumbai for facilitating the voluntary immigration of Indian Jews to Israel. Thousands of Indians had also traveled to Israel for courses and training in community development and agricultural technology. In a considerably short span of 13 years, from 1992 to 2005, both states had established strong bonds which strengthened their defense and security apparatus.

During Kargil Conflict in 1999, Israel supplied weapons that aided India in waging war with Pakistan. In 2002 Ariel Sharon, the Prime Minister of Israel, during his visit to India, accompanied by thirty influential businessmen, beard the witness that Israel was committed to strengthening its economic and trade ties with India. Six agreements were signed between the two countries, including environment, cultural education exchange program, combating illegal trafficking of drugs, health, visa waivers for diplomats and official passport holders.

Pakistan and India's antagonistic relationship could be observed since both countries gained independence in 1947 except for brief rapprochement periods. Their relations had always been strained due to the shadow cast by the shared history of numerous territorial claims and violent partition overshadowing their relationship. Factors dictating relations of both states include different ideologies, religions, and the legacy of colonial rule. Both states had fought three major wars and various conflicts. Both states also had undergone several war-like situations, such as military troop deployments at the international border in 2002. Except for the India-Pakistan War in 1971, the center point for these conflicts had always been the Kashmir conflict. The years 2004 to 2007 had shown an era of rapprochement from both sides. The 2014 elections in India and victory of Narendra Modi, a die-hard supporter of Hindutva ideology, also as an alleged facilitator during Gujrat Muslim riots, pushed Pak-India relations into the deep end. He faces some of the most harrowing clashes on the working boundary and Line of Control (LOC) during his era.

Since Israel's establishment in May 1948, Pakistan had refused to establish diplomatic relations with the newly born state. Both states came into contact in the early years of the 1950s. Despite the lack of formal diplomatic ties, there established close covert cooperation and coordination as witnessed in the Soviet-Afghan war and the Black September conflict. Since the end of the Cold War and the introduction of democratic Pakistan in the late 1980s, a new trend has emerged regarding Pakistan-Israel relations. Although this did not signal an immediate reversal of Pakistan's policy towards Israel, normalization has been seriously debated in public. Both the leaders, Ms. Bhutto and Nawaz Sharif, had indicated willingness to deal with the Jewish state. Prime Minister Ms. Bhutto's desire to visit the Gaza Strip in 1994 marked that a significant development in Pakistan's policy towards Israel. Yet Israel and Pakistan had regularly used their embassies and consulate-general in Istanbul and Ankara to mediate and exchange information with each other. In 2010 according to a report received by Washington, Pakistan was believed to have used its embassy in Ankara to pass on newly discovered information about possible attacks on Israeli targets in India in October 2009 by the same organization which had performed Mumbai attacks in 2008, according to Wiki Leaks.

Having discussed the nature of relations these three states had, it was vital to consider how Pakistan's uncordial ties with India and Israel and the strengthening Indo-Israel strategic collaboration would affect Pakistan. With the help of her ally Israel, India was enhancing its warfare capabilities in terms of network, communication, and electronic warfare techniques. India would create obstacles and vulnerabilities for Pakistan in terms of modern warfighting techniques. With the help of Israel, India developed current warfare capabilities, which enhanced the ability to operate a military force against its rivals without any time barrier (Khan, 2001).India also increased its long-range modern radars capabilities to infiltrate the territory of Pakistan.

Moreover, India also had installed defensive radars, missile launch sites, modern mobile launchers, and other sensitive installations that would cause Pakistan in the grave of danger. India could put Pakistan's security at risk because India's technological advancement and drones had the deadly explosive material that could destroy the direct targets in any battle filed or confrontation. Pakistan could not ignore the strategic significance of modern warfare capabilities possessed by India in the contemporary world.The most crucial facet of the Indian Israel strategic and defensive cooperation was countering the insurgencies, terrorism, and terrorist groups working against them and intelligence sharing against their enemies.

The intelligence agencies of India and Israel may instigate the sectarian strife in Pakistan and may fund Anti-Pakistan sentiments in Tehrike-Taliban of Pakistan. The army's media wing issued a 
statement that the Indian Research and Analysis Wing (RAW) supported and financed the rebel group based in Baluchistan. Still, there was no specific incident that could prove this statement. This research attempts to find out what are the strategic dimensions that exist between India and Israel? What are the convergences and divergences between Indo-Israel relations? How have Indo-Israel strategic partnerships created security threats and challenges for Pakistan? What are the implications of Indo-Israel's defensive cooperation against Pakistan? How does the development of advanced nuclear capabilities between India and Israel possess a security dilemma for Pakistan? The methodology of this study is based on social sciences research. The research design used in this research is based on the qualitative research method. This method is based on descriptive, historical, and explanatory approaches towards the concepts, issues, concerns, and strategies. The research is conducted using primary and secondary resources that are available within the premises of the researcher. The data has been collected through the internet, journal articles, research articles, books, reviews, reports, and newspapers.

\section{REVIEW OF LITERATURE}

Thematic literature review is used in this qualitative research proposal which focuses on the themes, ideas, and pattern of meanings within the given data. According to Abhyankar, twenty years have elapsed since full fledge diplomatic relations have been established between Israel and India. Both states illustrate historical dynamics as well as socio-political constructs and can testify to fast pace remodeling of world's balance of power that has occurred in a relatively short period of time. Comparison between both nations extends far and wide; religious communities have undergone nationalization process both suffer from challenges that arise concerning nationalist thought about the connection between ancient culture and new nationhood. The first decade of Indo-Israel relations has been concerned with changes that took place after Cold War and security as well as defense issues. The second decade of relationship has evolved to include industry, information and technology, trade, investments including people to people contact. India's good relations with Iran's neighbors, strategic weight in international arena, fast growing economy and potential market for services and goods including main investments serves as a foundation to further develop relations (Abhyankar, 2012).

According to Malhotra, Israel and Pakistan are similar states that came into being in the middle of $20^{\text {th }}$ century, both had similar dreams and religion-ideological nationalism runs in both states DNA. For both religion is a major element; Islam for Pakistan and Judaism for Israel and if taken out would make them fall to their ruin. In spite of Israel's hand in trying to communicate with Pakistan on numerous occasions its attempts have been rebuffed due to Pakistan's aversion towards it as it is pro-Arab and supporting Palestinian state. Despite this Pakistan needs to reassess its policy towards Israel due to the nation's increasing informal diplomacy with Arab states as both could benefit from a mutual partnership, strategically in Israel's case and economically in Pakistan's case (Malhotra, 2019).

Rehman critiques that Indeed, Indo-Israel strategic cooperation would be having impact on the South Asian strategic environment in generally for Pakistan. He says that anti-Islamic collaboration has been established in terms of racially discriminated patterns of Hindu and Zionist ideologies which have serious repercussions against Pakistan. This cooperation will impact on the strategic environment of Pakistan. The regional implication of Indo-Israeli nexus cannot simply be ignored, because the power balance of a nuclearized subcontinent needs a cautious examination of New Delhi's strategic connections with extra-regional powers.India preferred Israel in opposition of Pakistan as a potential ally and started a multi-dynamic strategic collaboration with it. The persuasion of national interest mainly inherited in the India's geo-strategic objective of acquiring the regional hegemonic position in South Asia by diminishing the role of emerging counterbalancing forces India has to acquire Israel's support (Rehman, 2017).

Khan states that Pakistan is highly apprehended over the emerging Indo-Israel strategic and defense relations. He says that Israel has developed meaningful relations with India not because of investing in the huge defense industry but to suppress the Pakistan's strong commitment to help the Middle Eastern states against Tel Aviv. It also wanted to stand against Pakistan in terms of its nuclear program that strengthens the Arab world especially Iran i.e. Israel's worse enemy. The emerging defense collaboration of India and Israel has created major challenges to the security and territorial 
integrity of Pakistan. Such defensive relationship has potential not only to dominate the global politics by altering the balance of power but also can dominate the entire Asian region (Khan, 2001).

According to Khattak, India and Israel's defense cooperation have far reaching implications for the security of Pakistan. India is already progressing with Israel in terms of network centric and electronic centric technology, such transformation may hinders and influence Pakistan military capabilities in modern warfare fighting techniques. These progresses create the security dilemma for Pakistan that its enemies have superiority in modern nuclear technology. The strategic significance of India and Israel's military capabilities is based upon their interest to counter the power politics against them and to deter their rivals from their advanced military power in the South Asian Region. This defense cooperation has serious impact on the regional and national security of Pakistan (Khattak, 2016).

\section{THEORETICAL FRAMEWORK}

\section{Security Dilemma}

The logic of the security dilemma argument given by Robert Herz is that an increase in one state's security can make the other state less secure, not because of misapprehension and hostility but the anarchic environment of international relations. The present state intention is benign, but it cannot guarantee that its intentions will either remain peaceful or become aggressive in the future. When a security dilemma is determined, the actions of one state are purely defensive, and the other one is offensive. The security dilemma is at the "heart of all conflicts." The two primary levels of the security dilemma highlight are postulations: capabilities, intentions, and potential of one state to create a condition of unresolvable uncertainty, and second appropriate state response must be determined against it.

\section{Offense Defense Balance}

Jervis explains when "being on the offense" has the advantage, it means that the easiest path is destroying the enemy and seizing its territory than adopting a defensive posture and defending one's homeland. However, when the defense has the advantage, it is not effortless to protect one's territory than to launch an offensive attack against the enemy. He separates two questions from this balance: whether the state must spend on defense to offset what is being paid by others for attacks. If a state chooses to spend only a single dollar, would it invest in defensive or offensive forces? The second question raised is that it is better to defend or attack given the condition of a state's strengths, and is there a motive to launch the first strike or absorb the other's attack?

All these aspects affect security dilemmas differently. The first aspect impacts the arms race. If the defense has an advantage, the state will probably avoid an arms race. Jervis explains that this will occur due to a stable equilibrium reached when both sides will react to an increase in security by bringing the number of forces roughly equal through small increases rather than a dramatic increase. The second aspect discusses whether the better option is to defend or attack, which impacts short-run stability. When the offense has the advantage, there is an increased chance that a war will take place. In such a situation where both states have first strike capabilities, and a "reciprocal fear" of surprise attack exists, there is no specific way to increase security without being considered a threat. When the defense has the advantage, everything will be reversed in favor of the state being attacked. The state should not fear a preemptive attack but prepare itself to receive it. In this case, it would not increase its military for increasing its security as it would consider it a waste. The situation will be stable, and states may cooperate (Jervis, 1978).

\section{Indo-Israel Strategic Cooperation Nature of Indo-Israel Relations}

Israel and India share a unique relationship. It is comprehensive and characterized by trust and pragmatism. It is relatively flexible and strategic, having withstood political transitions in both states over time. Israeli Prime Minister Benjamin Netanyahu and Indian Prime Minister Narendra Modi met at a UN general assembly in September 2014. This heightened the friendliness between the leaders of the two states. The next visit by Indian Home Minister Rajnath Singh to Israel in November 2014 visibly indicated the Indian government's devotion to the bilateral relationship. Numerous reasons can be attributed to India's interest in building a more secure connection with Israel. Tel Aviv has been a 
dependable partner on countless occasions. India has found Israel to be reliable, especially during any crisis. It has been a significant supplier of weapons that India has been forbidden to purchase in the global market. For instance, during the 1993 Kargil conflict, Israel responded to India's demands for critical war stores such as artillery munitions. In current times Israel holds the position of being the most extensive military supplier to India.

The second central defining element of the relations between these two states is pragmatism. Both India and Israel have had a severe difference of opinions regarding Iran and Palestine in recent times on Syria. Nevertheless, both states have not let these differences affect their relations. This can be reflected in the case of Palestine. India has supported Palestinians because it was the first non-Arab state to recognize Palestine liberation organization PLO in 1974. Over the recent years, even though Israel's stance on Palestinian issues has not changed, its ties with India have grown to the extent of overshadowing India's past attempts to support the Palestinian cause. Analysts have claimed that it is a result of lack of gains from adopting a pro-era policy; a significant reason for this policy was to have leverage over Pakistan, but Arab states did not support India as it wanted on its stance on alleged terrorism sponsored by Pakistan and Kashmir issue. Hence, a sense of discontent was generated as a result. Despite all this, New Delhi has not abandoned its traditional views on Palestine's cause but has managed to keep the issue separate from its ties with Tel Aviv. In the contemporary era, the two countries have united on the topic of terrorism. Both countries seemed to be facing similar nature of threats (Kumar, 2014).

\section{MUTUAL SECURITY CONCERNS}

Before understanding the strategic partnership between New Delhi and Tel Aviv, there is a need to understand the mutual security concerns that both states have. Presently any security cooperation is likely to revolve around a common enemy. In India's case, it is improbable that it will have the same concerns that Israel has over the unconventional threat of nuclear Iran in the form of chemical weapons or Islamic fundamentalists. (Eisenkot, 2019). Nor Israel is likely to perceive the China and Pakistan military threat the way India does. India will not abandon its close links with Arab allies due to its proximity to the region, labor migration to the Middle East, and dependency on Petroleum resources (Pant \&Bommakanti, 2019). Muslims of India who has their sympathies with Islamic countries in the past, to some extent, contributed to the absence of political relations between Israel and India due to their opposition against the State of Israel. Islamic fundamentalism, which is a fundamental goal in security debate with Israel, is not likely to be discussed between the two states as due to regional and domestic considerations, India is cautious as not to upset its ally Iran which it looks to for facilitating transit route into Central Asian region for economic relations and countering the anti-Indian campaign of Pakistan. It cannot simply abandon its military ties with China to ease India's concern on Israel's side. The absence of a common enemy has enabled both states over time to decrease their external security dependency on the US and Russia for providing financial assistance, technology, and weapons. India requires the technical assistance provided by India, and Israel needs the Indian domestic market for importing its hi-tech armory and weapons.

\section{Current Status of Partnership}

During Manmohan Singh's tenure as Prime Minister of India from 2004-2014, Israel has become one of its closest defense allies. Singh had adopted " "Look West" policy which focuses explicitly on maximizing access to Israeli technology and Gulf Energy resources. It is not only the national political leadership of India that the relationship has acquired a positive momentum but also the recent electoral political trends and its political system. Gujarat's top priority has been to promote technological and economic growth and seek Israel's assistance. At that time, Narendra Modi, now the Prime Minister of India, was the Chief Minister of Gujarat, and he led these efforts. Under his leadership, Gujarat and Israeli officials established ties to boost investment and trade, resulting in billions of dollars investments by Israel in thermal and solar power, water desalination, water recycling, infrastructure, and pharmaceuticals. Hence before the 2014 elections, a strong foundation for strategic cooperation had already been established. In the following years, Indo-Israeli ties have become vital to India's engagement in the Middle East. The decline in Palestine factor in regional politics has enabled compromise with Israel (Kumaraswamy, 2019). 
In February 2020, India's Bharat Electronics Limited and Israel Aerospace Industries signed an agreement to establish a maintenance and moral support center for India's aviation defense systems. Furthermore, on February 5, 2020, a strategic agreement was signed with Dynamic Technologies limited to work on unmanned aerial vehicles (UAV's). In 2020 India became a major contributor to Israel's defense sales, surpassing more than 1 billion dollars. According to Israel's Aerospace Industries (IAI), similar deals were made in 2017 for Barak 8 missiles which cost 2.5 billion dollars, and in 2018 for the surface to air missiles cost 1.3 billion dollars. IAI's president Nimrod Sheffer has stressed the importance of having Israel as its leading partner. Other Israel's major defense firms have expressed similar sentiments towards India. Elbit system has defined that the Indian market has potential, and its company is involved in numerous programs involving the defense sector. According to Begin Sadat Center for Strategic Studies, due to Indo-Israel's current ties, trade may increase to 20 billion dollars in the coming ten years. According to Calcalist, an Israeli media outlet from 2013 to 2017, India has exported 49 percent of Israel's arms. Under Israel's Ministry of Defense, India is one of the significant states involved in the International Defense Cooperation Directorate. Recently, another joint project was launched with the same companies, and Bharat Electronics has worked together with Israeli Companies in electro-optics and electronic warfare (Frantzman, 2020).

With a shift in Israel's regime, the New Israeli premier Naftali Bennet expressed his desire to advance the strategic interests between Tel Aviv and New Delhi. The joint military exercise in March 2021 in Abu Dhabi displays the increasing relationship between Israel and India. It portrays how Indian - Israel geostrategic relations are affecting the geopolitics of South Asia and the Middle East. A sharp distinction is generating between the strategic alliance after the Abrahamic between UAE, Israel, and India. On the other side,Turkey and Pakistan are also developing cordial relations. Though it is too early to state that new geopolitical blocks are growing in the Middle East, it is evident that the relationship between Israel, India, and Pakistan is not restricted to South Asia only.

\section{An Overview of India-Pakistan Relations}

Indo-Pak relations have always been hostile and complex due to the various political and historical events since the creation of Present-day Pakistan. The violent partition of British India has defined their relations during 1947, which commenced the Kashmir Conflict. After both states gained independence, they established diplomatic ties with one another. However, these ties were overshadowed by reciprocal territorial claims and violent partition. India and Pakistan have fought three major wars with one another, including undeclared war, and have been involved in several military standoffs and skirmishes. Numerous attempts have been made to improve their ties, notably the Lahore Summit, the Shimla Summit, and the Agra Summit. After the 1980s, their relations deteriorated further after the Siachen Conflict, intensification of Kashmir Conflict (1989), nuclear testing performed by both states in 1998, and the Kargil War of 1999. Confidence-building measures such as the ceasefire agreement in 2003 and Lahore-Delhi Bus Service successfully deescalated the relations between the two states. However, the terrorist attacks have impeded any progress made in their diplomatic relations.

\section{Challenges for Pakistan}

Israel has established purposeful relations with India for two main reasons: investing in India's substantial defensive industry and suppressing Pakistan's firm adherence to support and help Middle Eastern states. The strong growing relation between India and Israel makes a direct and indirect impact on Pakistan. It poses a threat to the balance of power in South Asia in general and Pakistan in particular. In the post-nuclear era, the looming defensive and strategic cooperation between India and Israel has also challenged Pakistan's security and territorial integrity.

\section{Pakistan's Concerns Regarding India-Israel Strategic Cooperation in the Post-Nuclear Era}

The aggressive nature of India and Israel's mutual interest has resulted in a close strategic partnership, a genuine area of concern for Pakistan. The anti-Islamic collaborations are well cemented in racially discriminatory Hindu-Zionist ideologies that leave severe repercussions for Pakistan in the Postnuclear era. The nature of well-established and structured bilateral relations between India and Israel contains several commonalities which place both the states into stronger diplomatic and strategic ties 
while locating in different regions. The national security professionals of both the states perceive their neighbors as potential rivals, and they prefer to undermine their sovereign existence against them. Such bilateral ventures, as a result, threaten the survival of their enemies. In this way, Israel feels threaten by the Arab states, whereas India perceives Pakistan and Chin as hostile. The prevailing relationship between Israel and India decided to antagonistically glaze their strategic cooperation to enthrall their adjoining territorial nations to accept their regional hegemonic schemes while offensively suppressing counterbalancing forces' role.

The essence of the assumption of Indo-Israel policy faces a dramatic shift in their new relations in the Post-Cold War era when the USSR was disintegrated, and the US emerged as the sole superpower. The cooperation between them, advanced in the field of defense. India has become the biggest importer of Israel's military industry, posing severe threats to territorially adjoining countries, especially Pakistan. This would leave a worse impact on Pakistan in terms of security because it will leave a conventional imbalance between India and Pakistan. The nuclear cooperation between India and Israel would inflict a sense of strategic inferiority in the Pakistani mindset. Consequently, both the countries would launch a preemptive strike against Pakistan and demolish its nuclear program. In this way, this nuclear cooperation between Israel and India resulted in a trilateral relationship of US-IndiaIsrael against the Pakistan and China to counter their power politics (Jaspal, 2017).

\section{Implications for Pakistan}

The offensive and defensive imbalance between Pakistan and India is the result of the Indo-Israel nexus. It has been contributing to the strategic miscalculations of the adversary's actual and perceived military capabilities. India has underrated the will and ability of Pakistan's armed forces to defend its status-quo by creating a strategic imbalance between them. The following are the implications of the Israel-India strategic cooperation in the post-Nuclear era are:

\section{Conventional Imbalance and Bulk of Cooperation Between India and Israel in Military Field}

India for several years has been regarded as an emerging, rising state with the development of a modest nuclear arsenal. India also sees Pakistan as an essential example of neo-realism because it is allied to the most powerful countries like Britain, the US, and China. Both India and Pakistan seek armed force to change the regional balance of power. This has created the conventional imbalance between both countries because of Israel's emergence of solid strategic cooperation between India and her. Though Pakistan has various ICMB's (Intern-continental Ballistic Missiles) and other advanced nuclear weapons, India is advancing its defense sector to gain regional hegemony and suppress Pakistan by gaining nuclear superiority. India being a deplorable state, has offended Pakistan with increased strategic cooperation between her and Israel. This has severe implications for Pakistan because it could collapse under the weight of its contractions within its state, e.g., the role of insurgencies and terrorism, etc. These contractions would not allow Pakistan to spend its colossal budget to enhance its defensive sector against India. India is more concerned about Pakistan's alliance with its rival China, and Israel is worried about Iran, a good friend of Pakistan. Pakistan has created its alliance with the enemies of both states. That is why to counter Pakistan's threat against them; both countries india and israel signed the Drone Dome System to counter Pakistan's smaller drones on the border. Israel defensive company Rafael and Bharat Electronics signed a considerable agreement to produce high altitude and medium-altitude UAVs such as the heron multi-mission tactical searcher, which will help India protect its borders. India underestimated Pakistan in sustained conventional and strategic force buildup. India has created a gap in its existing operational capabilities that can be seen in the recent event of Balakot (Cohen, 2011).

The overall growing conventional and nuclear imbalance and the asymmetry in the national power have been increasing. In the aftermath of the pandemic COVID-19, India has indicated that it will have a more significant impact on the indigenization for the modernization of its conventional forces. India aimed at securing a decisive quantitative and qualitative edge over Pakistan to deter China's capability. This will only be possible through the traditional imbalance and nuclear superiority of India over China and Pakistan. Pakistani threat perceptions are natural and ignited by the positioning of the bulk of Indian conventional forces against it and an extensive range of Indian ballistic missiles and curse missiles being tested and placed over the specific range of Pakistan. Over the following decades, India's diverse and sustained military modernization investment risks 
deterrence in the South Asian region. The technological asymmetries continue to grow beyond a certain point. Then it will create a further belligerency that will exacerbate the arms race instability and encourage irrational decision-makers preemptive inclination (Ahmed M., 2020).

\section{Threats Against the Position of Pakistan in the South Asian Region}

India poses a serious threat to Pakistan. The experts expressed this in the webinar titled "India Counterforce Capabilities and Options," hosted by the Strategic Vision Institute in 2019. They thought of pursuing the counterforce strategy against Pakistan, which included the massive defense allocations, fast-tracked allocations, modernizations, and planned integration of armed forces against Pakistan along their border. And India also called Israel, the US, and Russia for more arrangements if Pakistan attacks India after the abrogation of Kashmir status in 2019. The debates break out in Pakistan over the recognition of Israel because the two Islamic states, Bahrain and UAE (United Arab Emirates), recognize Israel and established full diplomatic with Tel Aviv. Hindu nationalist and Israeli anti-Muslim sentiments have constructed a narrative of Hindus as historical victims at the hands of Muslims. This narrative poses a threat to the territory of Pakistan because they may target Muslims as Islamic terror. Israel appears to be a threat to Pakistan because of Iran that is a point of convergence between them. The main reason between Pakistan and Israel is ideological and cultural rather than geopolitical (khan, 2020).

\section{Israeli Transfer of Technologically Advanced Military Arsenal to India: Security Threats to Pakistan}

Israel and India plan to crank up their already expensive defensive partnership by producing and developing high-tech weapons systems and exporting to their other friendly counties in the contemporary era. The primary function of this Sub Working Group (SWG) is on defense industrial cooperation. Its central role is to transfer technology, security, artificial intelligence, and innovation to third countries. Israel has become the fourth leading arms supplier of India in the last two decades. Now, the Indian defense industry is becoming stronger. Israeli defense companies like Elbit, Elta, and Rafael Advanced Defensive System have formed joint ventures with Indian defense companies. India has contained a wide range of Israeli weapons over the past few years, e.g., Airborne Warning and Control System, Heron, Searcher 2, Harop Drones, Barak Anti-Missile Defense System, Spyder Quick Reaction, and Anti-Aircraft Missile System. A host of Israeli missiles also include precisionguided munitions, from Pythons to Derby Air-to-Air Missiles to Crystal Maze and Spice 2000 Bombs.

For example, as India Air Force (IAF) contains Spice 2000 bombs kits. The IAF used these in their raid on an alleged Islamist group training at Balakot in Pakistan's northwestern Pakhtunkhwa province in February 2019. It converts the $2000 \mathrm{lb} \mathrm{Mk} 84$ and BLU-90 gravity bombs into the standoff anonymous weapons system to a 60km range strike against Pakistan. It threatened Pakistan's national security that if Pakistan interferes in its unilateral Kashmir issue, it will attack Pakistan at first. This attack was against Islamic terrorism from India and was supported by the Israeli weaponry system (Bedi, 2020).

\section{Conventional, Missile, and Nuclear Weapons Arms Race Between Indo-Israel and Pakistan and Resultant Economic Imbalances}

At the global level, the concept of balance of power may have become superannuated because of new realities and trends of the world. But the similar idea with all its results, including the military anticipation, alliances, suspicion, and threats, seems to be wholly practical in India and Pakistan and a threatening situation for its economy. If Pakistan spends its massive budget on defensive purposes, then there is a chance its economy could collapse. India's economy is more robust and is the $3^{\text {rd }}$ largest military budget spender globally, up to 91 billion dollars (49\% billion dollars per year). Israel is $15^{\text {th }}$ ranked in the world, which is up to 20 billion dollars. Pakistan only spends 9 billion dollars. Due to its fragile economy, Pakistan cannot compete with India and Israel in the nuclear weapons arms race. Pakistan's nuclear program has a reciprocal relationship with India's nuclear weapon policy. Pakistan always claimed that it had developed nuclear weapons to counter India's offensive threat against them. Growing Israel and India's bilateral relationship generates classic military, security, economic, and regional hegemonic implications and including the proliferation of military technologies, arms racing, and reciprocity of national policies for defense and deterrence. India and Pakistan have seriously 
engaged in the strategic competition and enduring importance of military security. The risk of threat and actual use of military force between them is a fundamental cause of the crisis. The belligerent interstate relation of India and Pakistan, including the conventional, missile, and nuclear arms weapons race, pose an unacceptable risk of strategic instability and intensifies the insecurity of both countries. But the arms control didn't remain for a long time because of India and Israel's strategy of balancing terror against the Pak-China alliance (Waqar, 2019).

\section{CONCLUSION}

The south Asian region especially india and pakistan have been subjected to tensions between the states since they gained independence from the British colonial empire. The security paradigm of the region underwent a structural change after the post-nuclear era. Since 9/11, the Israeli factor in the Indo-Pak relations impinges upon the most devastating rivalry between the two countries. The bilateral cooperation between India and Israel is based on mutual benefits. Both the countries share a common interest in defense, trade, intelligence sharing, counterterrorism, and internal security. Since the post-nuclear era, Israel has been silently inclined with India against the "Anti-Islamic Coalition". Since the beginning of the post-nuclear age, the Middle Eastern and South Asian region has posed a severe threat to the international community's peace and security. Joint military cooperation has evolved over the years.

The military cooperation between India and Pakistan proved harmful to India and Pakistan's fragile balance of power. At the international forum, Pakistan faces opposition from a hostile bloc; having cordial relations with India will significantly challenge its interest in the contemporary era. The growing ties between India and Israel pose a significant threat to Pakistan's security and stability in the post-nuclear era. It is undermining the strategic depth of Pakistan in the region. Both the states, India and Israel, have common intentions to create obstacles for Pakistan in all international forums and keep her from international actors. Israel's multifaceted supply of military weapons and advanced technology to India can give both qualitative and quantitative superiority over the states in the South Asian Region. And it will have the worse impact on Pakistan because there will be a conventional imbalance between India and Pakistan. Besides the traditional dimension, the cooperation in the defensive field in the post-nuclear era between India and Israel will attempt to inflict a sense of strategic inferiority in the mindset of Pakistan. In this way, the Indian dream of regional hegemony will disrupt the security environment of the South Asian Region. Thus, the US is becoming an ignorable factor in the Indo-Israel relations, but without achieving US' confidence, both countries can't maintain the concrete bilateral bond.

Furthermore, the military domain of the bilateral relations of India and Israel profoundly upset the regional nuclearized order of the South Asian region. The belligerent strategic behavior of India portrays a worrisome picture for Pakistan. India and Israel's strategic partnership are actively lobbying the international community to push Pakistan into critical circumstances. And this close bilateral bond has become the genuine area of concern for Pakistan. Their mutual concerns and interest are based on the qualitative weapons, modernization, and cooperation in the naval port, technological independence, and anti-terrorism arms buildup. India and Israel are experiencing a convergence of interest on a range of issues. Both are focusing on military modernization and identifying Islam as amutual foe.

Indo-Israel has established a vibrant relationship by strengthening its defensive and security apparatus in a relatively long span of two decades of formal diplomatic relations. The long-standing bilateral relationship of India and Israel based on similar goals assists each other in playing a significant role in their regional politics. Such vital bilateral ventures, for that reason, threatened the survival of adjoining countries. For instance, India feels threatened by China's bilateral relationship with Pakistan, whereas Israel feels threatened by Arab states. The geostrategic thrust of both the nations sparked an unending nuclear missile race in the Middle Eastern and South Asian Regions. India has become the second-largest importer of the Israeli defense industry in Asia. During the Prime Minister Modi regime, India expanded its trade ties vastly and set up a joint fund for research and development to promote the technology trade. Israel also eagers to deepen the relationship with India to use her support in the international polity. India's interest is to play along and take advantage of this opportunity to assist Israel in its defensive industry. 
National security is a primary and permanent interest for all nations. National security has been the first and foremost agenda for Pakistan too. The security of Pakistan has been affected in the case of the India and Israel nexus as Pakistan threat perception is based on India's high advanced military proficiency and Israeli joint military ventures with India. It is difficult for Pakistan to compete India in the conventional arms race because Pakistan's fragile economy can't take the traditional arms procurement. So, in this kind of scenario, Pakistan would have no other option but to rely on its nuclear program to deal with any threat from the Indo-Israel strategic alliance.

Indo-Israel strategic ties are well developed and based on mutual threat perceptions and benefits. Both states share common interests, covering defense trade, counterterrorism, intelligence sharing, and internal security, and their bilateral ties will continue to develop in defense, especially for India. For Israel, India's domestic market is perfect for importing its defense technology and weaponry; for India, it needs the technical assistance that Israel provides to assert its hegemony in the South Asian region. Despite having such close strategic ties, several factors seem to impede their relations; they include US concerns about India building up its military capability as it fears it will increase the risk factor of the arms race. The second major factor is Iran; while Iran and India have good relations, Israel and Iranian ties cannot be said. Israel views Iran as an epicenter of terrorism and an incredibly violent state. Thirdly, India's domestic situation somewhat challenges the Indo-Israel associations due to its large Muslim community, which is against establishing ties with Israel and the Communist Party of India.

The strategic alliance between India and Israel has severe implications for Pakistan. It poses tough challenges to Pakistan's deterrence capability. The balance of power will shift in favor of India by eroding the shifting strategic equilibrium. The irregularity is created between the conventional and non-conventional balance of power of India and Pakistan. Israel is the state of the art of weapons system, and it will help India create the solid and huge defense industry of the $21^{\text {st }}$ century. India's close relationship with Israel will deploy the advanced missile over the border of Pakistan. The collaboration of India's defense and missile system with Israel got superiority over Pakistani nuclear warheads. The Israeli anti-missile system will protect the Indian navy and air missiles against Pakistan. India RAW (Research and Analysis Wing) has collaborated with Israel's intelligence MOSSAD to make a dangerous move against the Muslim world. Indo-Israel nexus creates a potentially destabilizing force in the region against Pakistan. India and Israel's growing solid bilateral strategic relations in the $21^{\text {st }}$ century will destabilize the South Asian region and have dangerous consequences.

\section{RECOMMENDATIONS}

Security (internal and external) has been the foremost concern for Pakistan. In the institutionalized Indo-Israel strategic bilateral cooperation, Pakistan's threats are based on India's high military proficiency. Pakistan must take concrete steps to eliminate these security threats. The efforts should be made for the security of Pakistan. To enhance security, there should have a more effective system and foreign policy decision mechanism. The following recommendations have been made:

- Pakistan must develop diplomatic relations with Israel. Pakistan strategist believed that her friendship with Israel would prevent Indian lobbies in the US from launching efforts to isolate Pakistan at an international forum.

- Pakistan should look towards China. China is an excellent opportunity for Pakistan because the Sino-Pak alliance will significantly impact Indo-Israel's nexus strategic objectives in the region. This will help Pakistan to counter the growing hegemony of India in the South Asian region. China is a market of actual defensive missile production but a significant global player dominating India and Israel at an international forum.

- With such an alarming situation created by India and Israel's strategic capabilities advancement, Pakistan must develop strong bilateral relations with India's rivals. For instance, Pakistan would be advantageous if it gets full membership of the Shanghai Cooperation Organization (SCO), it will be the best platform for Pakistan to deter its two rivals (India and Israel).

- The policy that would play an influential role in countering India and Israel is enhancing Pakistan's defensive industry by developing mutual cooperation with Russia and China. With the help of these two actors. Pakistan should produce vertically large manufacturing and research wing to create long-range and short-range advanced missiles. 
- The Indo-Israel strategic cooperation may undermine by Pakistan's strategic partnership with China. Taking into consideration the recent transfer of advanced nuclear and missile technology to India by Israel, Islamabad needs to increase the quantity and quality of its nuclear weapons and pot for second-strike capability in underground tunnels or at sea amongst a robust command and control structure for strengthening nuclear deterrence against New Delhi to prevent any future limited or total war.

- Pakistan needs to improve its defense technology by enhancing its nuclear capabilities and advancing its surveillance and reconnaissance capabilities. In addition to this, it needs to work in joint partnership with China to advance in nuclear technology.

\section{REFERENCES}

Abhyankar, R. (2012). The Evolution And Future Of India-Israel Relations.Tel Aviv: S. Daniel Abraham Center.

Ahmed, M. (2020). Risks Of Asymmetry And Future Escalation In India-Pakistan Relations.Washington D.C: South Asian Voices, Stimson Center.

Bedi, R. (2020). DRDO NEWS. Metcalfe House, Delhi: Defense Science Library.

Cohen, S.P. (2011). India, Pakistan And Kashmir. Journal Of Strategic Studies, 1-23.

Frantzman, S. (2020, Feburary 18). New Joint Ventures Hint At 'Burgeoning Relationship' Between Israel And India. Retrieved From:

Https://Www.Defensenews.Com/Industry/2020/02/18/New-Joint-Ventures-Hint-At-

Burgeoning-Relationship-Between-Israel-And-India/

Jervis, R. (1978). Cooperation Under The Security Dilemma. World Politics, 167-214.

Jervis, R. (2001). Was The Cold War A Security Dilemma? Journal Of Cold War Studies, 36-60.

Khan, I.A. (2020, November 28). Indian Actions Pose Threat To Region's Strategic Stability. DAWN.

Khan, M. A. (2020, December 21). RAW's Propaganda Against Pakistan. The Nation.

Khan, Z. (2011). Development In Indo-Israel Defence Relations Since 9/11: Pakistan's Security Concern And Policy Options. South Asian Studies, 131-151.

Khattak, M. U. (2016). Strategic Significance Of Indo-Israel Defence Collaboration: Implications For Pakistan's Security. IPRI, 49-69.

Kumar, T. (2015). India And Israel: Reinforcing The Partnership. New Delhi: ORF Research .

Kumaraswamy, P. (2019). India's New Israel Policy: How The Decline Of The Palestinian Issue And Economic Reorientation Accelerate Indo-Israeli Cooperation. Berlin: German Institute For International And Security Affairs.

Malhotra, D. (2019, September 30). Pakistan-Israel Relations: Decoding The Strategic Silence. Retrieved From: Https://Www.Claws.In/Publication/Pakistan-Israel-Relations-Decoding-TheStrategic-Silence/

Rehman, A.U., \& Jaspal, Z.N. (2018). Indian Strategic Thinking \& Partnership With Israel: Implications For Pakistan. Institute For Strategic Studies, Research \& Analysis - Issra, 73-84.

Waqar, A. (2019, March 7). Nuclear War Between India And Pakistan. Retrieved From: Https://Theconversation.Com/Nuclear-War-Between-India-And-Pakistan-An-Expert-

Assesses-The-Risk-112892 